\title{
MAXIMAL RESPIRATORY PRESSURES, THEIR ASSOCIATION WITH SPIROMETRIC PARAMETERS, SWIMMING SKILLS AND CHANGES DUE TO IMMERSION IN WATER
}

\author{
Maija Rumaka ${ }^{1}$, Imants Upitis ${ }^{2}$, Juris Grants², Liga Aberberga-Augškalne ${ }^{1}$ \\ Riga Stradinš University', Riga, Latvia \\ Latvian Academy of Sports Education², Latvia
}

\begin{abstract}
Research background and hypothesis. We checked hypothesis that swimming skill improvement is more dependent on inspiratory muscle strength than endurance volume to be ventilated.

Research aim was to determine associations between maximal static inspiratory (MIP) and expiratory (MEP) pressures, swimming skills, parameters of forced spirometry.

Research methods. Investigation involved 62 female students (age $22.13 \pm 1.3$ years, height $168.4 \pm 6.6 \mathrm{~cm}$, and weight $61.3 \pm 7.0 \mathrm{~kg}$ ) of the Latvian Academy of Sports Education. All of them were non-smokers. Swimming skills in four strokes were evaluated by a swimming coach. MIP and MEP were measured at the mouth level outside the swimming pool and repeated in the swimming pool while the subject was immersed up to the neck level. Forced spirometry was performed according ATS guidelines outside the water.

Research results. Average value for MIP outside the water was $109 \pm 30 \mathrm{~cm} \mathrm{H}_{2} 0$ and for MEP it was $147 \pm 33 \mathrm{~cm} \mathrm{H} \mathrm{H}_{2} 0$. There was positive correlation between peak expiratory flow and MIP, MEP, and the rate of increase of both pressures $(p<0.05)$. Forced vital capacity was not related to maximal pressures. Faster rate of inspiratory pressure increase was positively related to forced inspiratory volume in one second $(p<0.05)$. There was a significant decrease of MIP and the rate of increase of inspiratory pressure in the immersion state while no changes of expiratory parameters were observed.

Discussion and conclusions. Swimming skill improvement is more dependent on inspiratory muscle strength than volume to be ventilated. Students with higher PEF have higher respiratory pressure parameters. Immersion in water decreases MIP, IMRPD and increases IMMRR. Changes of these parameters due to immersion are not related to swimming skills.
\end{abstract}

Keywords: maximal inspiratory pressure, maximal expiratory pressure, swimming education, immersion in water.

\section{INTRODUCTION}

$\mathrm{D}$ uring exercise demand for oxygen increases, which stimulates the increase of volume of air exchanged in lungs. Compared to activities not in the water, in swimming time allowed for inspiration is reduced. Respiratory muscle strength and speed of their contraction should be important to breathe the required amount of air in a short time when swimmers' heads emerge on the surface of the water.

It is known that swimmers can generate greater maximal respiratory pressures and specific training can increase the strength within several weeks (Tzelepis et al., 1999; Sonetti et al., 2001). The effect of specific respiratory muscle training on exercise performance is controversial (Wells et al., 
2005). The information about the relationship between swimming skill development and required respiratory training is not available.

The purpose of this study was to determine the associations of respiratory pressure and spirometric parameters with swimming skills as well as changes of respiratory pressures due to immersion into water to the neck level.

\section{RESEARCH METHODS}

Investigation involved 62 female students (the mean age $22.13 \pm 1.3$ years, height $168.4 \pm 6.6 \mathrm{~cm}$, and weight $61.3 \pm 7.0 \mathrm{~kg}$ ) of the Latvian Academy of Sports Education who attended swimming instruction programme, all of them were nonsmokers. Competitive swimmers were excluded from the investigation. A written informed consent was obtained from each student. The study was approved by the Ethics Committee of the Riga Stradinš̌ University.

Swimming skills in four styles (front crawl, back crawl, breaststroke, and butterfly) of each student were evaluated by a swimming coach at the end of 6-week swimming instruction programme. According to the evaluation the students were divided in three groups:

Group 1 - students with the poor swimming skills $(\mathrm{n}=14)$;

Group 2 - students with the moderate swimming skills $(\mathrm{n}=32)$;

Group 3 - students with the good swimming skills $(\mathrm{n}=16)$.

Maximal expiratory and inspiratory pressure measurements at the mouth level were done with Micro RPM (England) at the end of the swimming instruction programme. The MEP, MIP, maximal rate of pressure development during expiration (EMRPD) and inspiration (IMRPD), maximum relaxation rate in expiration (EMRR) and inspiration (IMMR) were used for the evaluation. The test was repeated three times in the room and in the swimming pool, where the subject was immersed into water to the neck level.

Forced spirometry test according ERS/ATS guidelines was performed in the room. Forced vital capacity (FVC), forced expiratory volume in one second (FEV1), and peak expiratory flow (PEF) were analysed.

The data were analysed using SPSS programme. The differences between parameters in the air and the water were evaluated using Mann Whitney test. Differences of parameters between students with poor and good swimming skills were determined by Kruskal-Wallis and Wilcoxon tests. The relationships between parameters were assessed using Spearman's correlation. The alpha level of $\mathrm{p} \leq 0.05$ was required for statistical significance.

\section{RESEARCH RESULTS}

Minimum, maximum, mean and standard deviations of respiratory parameters are given in Table 1.

There were no significant differences in spirometric variables between students of three swimming skill groups. The mean MIP for students with moderate and good swimming skills was greater than that for students with poor swimming skills (Figure 1). The observed mean values of IMRPD and EMRPD were higher for students with moderate and good swimming skills (Figure 2). However, these differences were not statistically significant. There were no significant inspiratory and expiratory MRR differences between students with poor and good swimming skills.
Table 1. Respiratory pressure test and spirometry results
Note. MIP - maximal inspiratory pressure; EMRPD - maximal rate of pressure development in expiration; IMRPD maximal rate of pressure development in inspiration; FVC - forced vital capacity; FEV1 - forced expiratory volume in one second; PEF - peak expiratory flow; MEP maximal expiratory pressure.

\begin{tabular}{|l|c|c|c|c|}
\hline \multicolumn{1}{|c|}{ Parameter } & Minimum & Maximum & Mean & SD \\
\hline MEP, cm H $\mathrm{H}_{2} \mathrm{O}$ & 90 & 240 & 147 & 33 \\
\hline $\mathrm{MIP}, \mathrm{cm} \mathrm{H} \mathrm{H}_{2} \mathrm{O}$ & 55 & 184 & 109 & 30 \\
\hline EMRPD & 120 & 1694 & 567 & 325 \\
\hline IMRPD & 107 & 1167 & 342 & 192 \\
\hline FVC, 1 & 3.32 & 5.88 & 4.46 & 0.52 \\
\hline FEV1, 1 & 3.16 & 4.68 & 3.95 & 0.35 \\
\hline PEF, $1 / \mathrm{s}$ & 5.10 & 11.20 & 7.14 & 1.15 \\
\hline
\end{tabular}



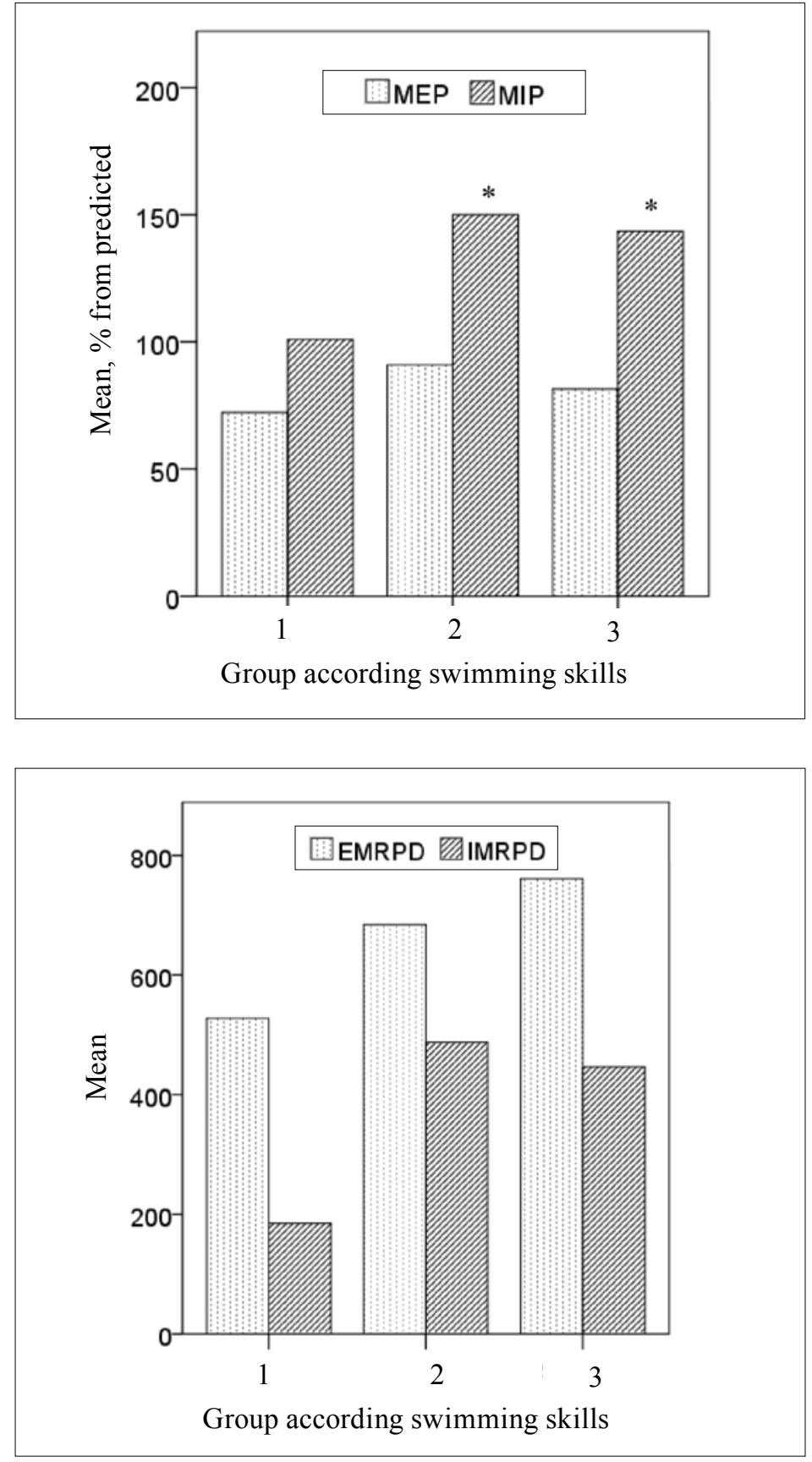

Figure 1. Mean maximal expiratory (MEP) and inspiratory (MIP) pressures in per cent from the predicted value in the room for students with different swimming skills

Note. ${ }^{*}-\mathrm{p}<0.05$ against group 1 due to Mann-Whitney test.

Figure 2. Mean maximal rates of pressure development in expiration (EMRPD) and inspiration (IMRPD) in the room for students with different swimming skills
There was a statistically significant positive correlation observed between maximal respiratory pressures and PEF as well as maximal rate of pressure development in expiration and inspiration and PEF (Table 2), but there were no significant correlations between respiratory pressure test parameters and other spirometric variables.

Table 2. Spearman's correlations between respiratory pressure and spirometric variables

\begin{tabular}{|l|c|c|c|c|}
\hline Variables & MEP & EMRPD & MIP & IMRPD \\
\hline PEF & $0.28 *$ & $0.32 *$ & $0.29 *$ & $0.33^{*}$ \\
\hline FEV1 & & & $0.32 *$ & \\
\hline
\end{tabular}

Note. ${ }^{*}-\mathrm{p}<0.05$, according to Spearman's correlation test.
At the immersion into the water to the neck level students produced lower MIP, IMRPD and higher IMRR than in the room $(\mathrm{p}<0.05)$ (Figures 2,3 and 4). There was a decrease of expiratory parameters (MEP and EMRPD) observed, however these differences were not statistically significant.

There were no statistically significant differences observed in respiratory pressure test parameters between students of the three groups according to their swimming skills. 
Figure 3. Mean maximal expiratory (MEP) and inspiratory (MIP) pressures in the room (_1) and when immersed into the water to the neck level ( 2$)$

Note. ${ }^{*}-\mathrm{p}<0.05$ compared to MIP 1 according to Wilcoxon paired rank test.

Figure 4. Mean maximal rates of pressure development in expiration (EMRPD) and inspiration (IMRPD) in the room $(1)$ and when immersed into the water to the neck level ( 2$)$

Note. ${ }^{*}-\mathrm{p}<0.05$ compared to IMRPD_1 according to Wilcoxon paired rank test.

Figure 5. Mean maximal relaxation rates in expiration (EMRR) and inspiration (IMRR) in the room ( 1$)$ and while immersed into the water to the neck level ( 2)

Note. ${ }^{*}-\mathrm{p}<0.05$ compared to IMRR_1 according to Wilcoxon paired rank test.
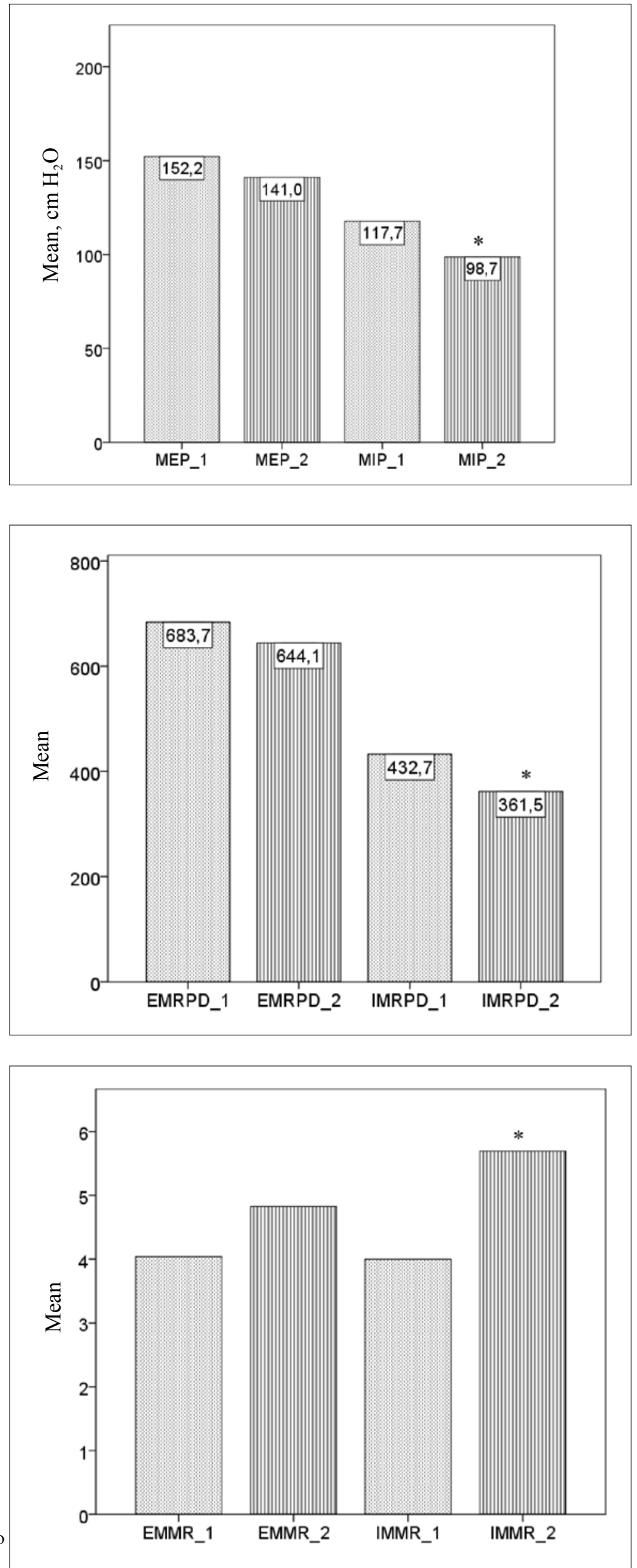


\section{DISCUSSION}

The lung volumes and respiratory pressures in our study for all the females were normal in respect to predicted values (ATS/ERS - Statement on Respiratory Muscle Testing, 2002). There were no statistically significant differences in lung volumes observed between students with different swimming skills. We observed positive association of PEF with maximal respiratory pressures and maximal rates of pressure development in expiration and inspiration. Even stronger relationships were observed by other authors (Harik-Khan et al., 1998) indicating that respiratory muscle strength is an important indicator of the speed of airflow.

It is known that swimming and diving stimulates development of larger than normal static lung volumes and flow rates. These sports strengthen inspiratory muscles that work against additional resistance of the mass of water compressing the chest and increase maximal respiratory pressures (Phervani et al., 1989; Cordain et al., 1990; Kesavachandran et al., 2001).

Higher inspiratory muscle strength in our study was positively related to swimming skill evaluation estimate. While swimming, compared to running or cycling, athlete uses larger tidal volumes and breathes less frequently (Rodriguez, 2000). Persons with greater inspiratory muscle strength can ventilate lungs properly and improve their stroke mechanics. It is known that swimmers also need faster inspiration to inhale enough air in the limited time when swimmers mouth is above the water level. In our study there was no significant difference in the speed of inspiratory muscle contraction between students of different swimming skills. Probably, for the development of proper swimming skill, it is not necessary to have very fast contractions of respiratory muscles, but if the swimmer wants to achieve the faster speed of swimming, it is crucial (Clanton et al., 1987; Cordain, Stager, 1988; Lomax, Castle, 2011). However, there was a tendency to have faster contractions in the group of students with higher swimming skills. The absence of differences could be explained with small groups of students who had poor and good swimming skills.

The MIP and IMRPD decreased and IMRR increased due to the immersion into the water compared with the values obtained in room. This could be caused by the effect of increased hydrostatic pressure of water on thoracic cavity. The water pressure works against the force created by inspiratory muscles and decreases the absolute value of maximal pressure generated during inspiration as well as the speed of inspiratory muscle contraction. Immersion in upright position causes compression of abdominal cavity, increasing resistance to diaphragm (Schoenhofer et al., 2004) and further decreasing MIP value. The increased pressure from outside increases the pressure in the thoracic cavity, favouring to the faster increase in pressure when inspiratory muscles relax (Cordain, Stager, 1988; Withers, Hamdorf, 1989).

\section{CONCLUSION AND PERSPECTIVES}

In conclusion, swimming skill improvement is more dependent on inspiratory muscle strength than volume to be ventilated. Immersion into the water decreases MIP, IMRPD and increases IMMRR. Changes of maximal inspiratory pressure test parameters due to immersion are not related to swimming skills.

\section{REFERENCES}

ATS/ERS. (2002). Joint statement on respiratory muscle testing. American Journal of Respiratory and Critical Care Medicine, 166, 518-624.

Clanton, T. L., Dixon, G. F., Drake, J., Gadek, J. E. (1987). Effects of swim training on lung volumes and inspiratory muscle conditioning. Journal of Applied Physiology, 62 (1), 39-46.

Cordain, L., Stager, J. (1988). Pulmonary structure and function in swimmers. Sports Medicine, 6, 271-278.

Cordain, L., Tucke, A., Moon, D., Stage, J. M. (1990). Lung volumes and maximal respiratory pressures in collegiate swimmers and runners. Research Quarterly for Exercise and Sport, 61 (1), 70-74.
Harik-Khan, R. I., Wise, R. A., Fozard, J. L. (1998). Determinants of maximal inspiratory pressure. American Journal of Respiratory and Critical Care Medicine, 158, 1459-1464.

Kesavachandran, C., Nai, H. R., Shashidhar, S. (2001). Lung volumes in swimmers performing different styles of swimming. Indian Journal of Medical Sciences, 55 (12), 669-676.

Lomax, M., Castle, S. (2011). Inspiratory muscle fatigue significantly affects breathing frequency, stroke rate, and stroke length during 200-m front crawl swimming. The Journal of Strength and Conditioning Research, 25, 2691-2695. 
Phervani, A. V., Desai, A. G., Solepure, A. B. (1989). A study of pulmonary function of competitive swimmers. Indian Journal of Physiology and Pharmacology, 33 (4), 228-232.

Rodriguez, F. A. (2000). Maximal oxygen uptake and cardiorespiratory response to maximal $400-\mathrm{m}$ free swimming, running and cycling tests in competitive swimmers. The Journal of Sports Medicine and Physical Fitness, 40 (2), 87-95

Schoenhofer, B., Koehler, D., Polkey, M. I. (2004). Influence of immersion in water on muscle function and breathing pattern in patients with severe diaphragm weakness. Chest, 125, 2069-2074.

Sonetti, D. A., Wetter, T. J., Pegelow, D. F., Dempsey, J. A. (2001). Effects of respiratory muscle training versus placebo on endurance exercise performance. Respiration Physiology, 127, 185-199.

Tzelepis, G. E., Kadas, V., McCool, F. D. (1999). Inspiratory muscle adaptations following pressure or flow training in humans. European Journal of Applied Physiology, 79, 467-471.

Wells, G. D., Plyley, M., Thomas, S., Goodman, L., Duffin, J. (2005). Effects of concurrent inspiratory and expiratory muscle training on respiratory and exercise performance in competitive swimmers. European Journal of Applied Physiology, 94 (5-6), 527-540.

Withers, R. T., Hamdorf, P. A. (1989). Effect of immersion on lung capacities and volumes: Implications for the densitometric estimation of relative body fat. Journal of Sports Sciences, 7 (1), 21-30.

\title{
MAKSIMALIOJO VALINGO KVE்PAVIMO SLE்GIO SĄSAJOS SU KITAIS SPIROMETRINIAIS RODIKLIAIS BEI PLAUKIMO IGŪDŽIAIS IR JO POKYČIAI KŪNUI PANIRUS İ VANDENI
}

\author{
Maija Rumaka ${ }^{1}$, Imants Upitis², Juris Grants², Liga Aberberga-Augškalne ${ }^{1}$ \\ Rygos Stradinio universitetas ${ }^{1}$, Ryga, Latvija \\ Latvijos sporto pedagogikos akademija ${ }^{2}$, Ryga, Latvija
}

\begin{abstract}
SANTRAUKA
Tyrimo pagrindimas ir hipoteze. Tikrinome hipotezę, kad plaukimo igūdžių tobulëjimas labiau priklauso nuo ¡kvėpimo raumenu jègos nei nuo jų ištvermès.

Tikslas - nustatyti maksimaliojo valingo kvėpavimo slègio ir kitų aktyvios spirometrijos rodiklių bei plaukimo igūdžių sąsajas.

Metodai. Buvo tiriamos 62 Latvijos sporto pedagogikos akademijos studentès (amžius $-22,13 \pm 1,3 \mathrm{~m}$., ūgis $-168,4 \pm 6,6 \mathrm{~cm}$, kūno mase $-61,3 \pm 7,0 \mathrm{~kg}$ ). Visos jos nerūkè. Plaukimo igūdžius vertino jų plaukimo treneris. Maksimalusis statinio ikvėpimo ir iškvèpimo slègis bei aktyvaus valingo kvėpavimo rodikliai buvo matuojami burnos lygyje, tiriamajam esant sausumoje, paskui maksimalusis statinio įkvèpimo ir iškvẻpimo slègis dar kartą matuotas vandenyje, t. y. plaukikei iki kaklo panirus i vandeni.

Rezultatai. Vidutiniškai maksimaliojo statinio įkvèpimo slègio rodikliai ne vandenyje siekè $109 \pm 30 \mathrm{~cm} \mathrm{H}_{2} 0$, iškvèpimo $-147 \pm 33 \mathrm{~cm} \mathrm{H}_{2} 0$. Aptikta teigiama maksimaliojo iškvépimo ir maksimaliojo statinio įkvépimo bei iškvèpimo slègio, abiejų slègio rodiklių didèjimo greičio koreliacija. Aktyvaus valingo kvèpavimo tūris nebuvo susijęs su abiem maksimaliojo slègio rodikliais. Greitesnis ikkvèpimo slègio padidejjimo tempas buvo teigiamai susijęs su santykiniu aktyvaus valingo kvẻpavimo tūriu (per vieną sekundę, $\mathrm{p}<0,05$ ). Reikšmingai sumažèjo maksimaliojo įkvėpimo slègis bei jo padidėjimas dèl panirimo į vandeni, tačiau jokių iškvėpimo rodiklių pokyčių nebuvo užregistruota.

Aptarimas ir išvados. Plaukimo igūdžių tobulèjimas labiau priklauso nuo ịkvèpimo raumenų jẻgos nei nuo jų ištvermès. Plaukikès, kurioms būdingas aukštas maksimaliojo iškvėpimo greičio rodiklis, geba pasiekti ir aukštesnio lygmens kvėpavimo slėgio rodiklius. Panirus ỉ vandeni, sumažèja maksimalusis statinio įkvėpimo bei iškvėpimo slëgis, didèja kvẻpavimo dažnis. Šių rodiklių pokyčiai dèl panirimo ị vandeni nèra susiję su plaukimo igūdžiais.
\end{abstract}

Raktažodžiai: maksimalusis įkvėpimo slègis, maksimalusis iškvėpimo slègis, plaukimo mokymas, panirimas i vandeni. 